\title{
ICTs \& Internet Adoption in China's Tourism Industry
}

\author{
Jennifer Xiaoqiu Ma \\ Dimitrios Buhalis* \\ Haiyan Song \\ Centre for eTourism Research (CeTR), \\ School of Management, \\ University of Surrey, Guildford, GU2 7XH, UK
}

\section{ICTs \& Internet Adoption in China's Tourism Industry}

\begin{abstract}
The fast development of information communication technologies (ICT) and the expansion of the Internet have changed industry structures around the world. New technologies have been adopted in the tourism industry in Europe and America for more than 30 years, and the trend is likely to continue into the future. China, as a fast-growing developing country in Asia, is gaining importance in the international tourism market for its historical and cultural attractiveness as a destination. It is also becoming a booming tourism source country as its population starts travelling overseas. This study examines how the ICT and Internet gradually change the tourism industry structure in China; how important such changes are; and to where such changes will lead China's tourism industry. This exploratory research is conducted based on information collected from several tourism organisations, such as airlines, hotels, tour operators, visitor attractions and the tourism authorities within China.
\end{abstract}

Keywords: ICT, Internet, tourism, China

\footnotetext{
${ }^{*}$ Corresponding author. Tel: +44 1483 686332; Fax: +44 1483 686301, Email: d.buhalis@surrey.ac.uk.
} 


\section{Authors Biographical Details}

Following a successful career in the tourism industry Jennifer Xiaoqiu Ma completed the MSc in eTourism at the University of Surrey. She is currently working as sales and marketing director in a joint venture (China-New Zealand) aquarium in Beijing whilst translating Dr Buhalis' eTourism book to Mandarin.

Dr Dimitrios Buhalis is Course Leader MSc in eTourism and Director, Centre for eTourism Research (CeTR) at the School of Management, University of Surrey. He graduated with a BSc in Business Administration from the University of the Aegean in Greece and he completed his MSc and $\mathrm{PhD}$ degrees at the University of Surrey. He has been pioneering research on Information Communication Technologies for Tourism and he has written a number of books and articles on the topic. Dimitrios frequently advises the World Tourism Organisation, the World Travel and Tourism Council and the European Commission on ICTs and Tourism.

Professor Haiyan Song is Professor of Economics at the School of Management, University of Surrey. His main research area is in applied econometrics with a particular focus on modeling and forecasting aggregate demand and consumption. He holds a BA degree in Economics from the Dongbei University of Finance and Economics in China and a PhD in Economics from Glasgow Caledonian University. He has published widely in the areas of foreign direct investment in China, China's economic growth and foreign trade, emerging financial markets and the aggregate consumption and investment functions in China. Over the last few years, Professor Song has also developed an interest in tourism economics and has published a number of papers on tourism demand modeling and forecasting. 


\section{Introduction}

China has been one of the major international tourism destinations since early 1980s (CNTA, 2001, He et al, 2001, Lew and Yu, 1995). The same period has also witnessed the revolutionary development of information communication technologies (ICTs), especially the recent development in Internet. However, little research has been done to explore the ICT and Internet adoption status in the Chinese tourism industry and the impact of ICT on the structure of the industry. This paper concentrates on exploring the ICT applications and their impacts on the development and tourism industry structure in China. Using the existing theoretical framework on ICT and eTourism developments in other parts of the world, Europe and American in particular, this paper sets out to examine the current status of eTourism applications in China.

\section{Literature review}

Information communication technologies have been applied in tourism since the early adoption of Computer Reservation System (CRS) in airlines in 1950s and in the transformation to Global Distribution Systems (GDSs) in the 1980's. Hotel property management systems and hotel CRS systems appeared shortly afterwards, bringing switch companies into the market as well in order to improve interconnectivity and interoperability. However it is the development of the Internet that brought the revolutionary changes to the structure of the industry, by providing tourism principals, airlines and hoteliers, an opportunity to sell directly. Because of this development travel intermediaries that connected suppliers and consumers have faced a danger of being cut off and replaced. Travel agents felt the most pressure of such changes. The discussion of disintermediation and reintermediation has lasted for more than ten years and ever since the e-commerce model appeared along with the Internet booming. The implications of ICTs on the tourism distribution system has been discussed thoroughly and extensively in many published 
studies including Buhalis (2002, 2003), O'Connor (1999, 2000), Sheldon (1997), Inkpen (1998) and Cooper et al (2000), Palmer \& McCole (1999), Lang (2000) and Standing \& Vasudavan (2001).

The most recent developments in eTourism applications are at the destination level. By employing Internet, Intranet and Extranet, some destination management organisations (DMOs) have successfully integrated this function in promoting their destination, providing tourists with pre-trip and in-trip information; helping small and medium-sized tourist enterprises (SMTEs) to promote their products. Expanding internal management within DMOs into destination networking and promotion systems (Buhalis, 1993, 1998).

Dot-com entrepreneurs and other companies and investors have realised that the Internet should not cannibalise business models, but act as an enabler that empowers organisations to achieve their objectives. Technology itself cannot bring value to any tourism company. However, the strategic and efficient implementation of technology within a business can reduce operational costs and support the delivery of better products or services to customers. If managed properly ICTs help tourism companies and destinations to gain competitive advantage by either maintaining their price leadership in the market or by differentiating their product and services. This will eventually lead to the increase of value added to the company. It is from this point of view that strategic implementation of information technology and Internet become critical for all companies trying to survive in this new economy (Poon, 1993; Sheldon, 1997; Werthner \& Klein, 1999; Alford, 2000, WTO, 2001).

Hitherto, most published literature on eTourism has been based on the Internet and ICTs developments and case studies in Europe and America, with little effort being made to study the eTourism developments in China (Martinsoms, 2002 and McGregor, 2002). However, the huge 
market and great potential of the demand in China makes it imperative to appreciate how the technological transformation will influence the Chinese tourism industry structure. According to an online survey held by one of the official information websites (www.cnnic.com), the number of total Internet users in China doubled every year for the last three years. Therefore, eTourism applications in China are worth the attention of researchers considering the potential dynamic changes.

\section{Research Methodology}

This research aims to explore the level of adoption and the future potential of eTourism applications in China. As the research is examining a new study area, focusing on the supply-side of the Chinese tourism industry, qualitative approaches were used as the main research method, with the quantitative research as a complementary method. The research starts by answering such questions as what, where, how and why China's eTourism has been developed. It then concentrates on some analytical points and possible future trends. Most primary data was collected from interviews conducted with tourist companies of a number of key tourism sectors in Beijing, the capital city of China, as well as the heart of the country's tourism development.

The primary data was collected from 45 tourist organisations including airlines, hotels, tour operators, visitor attractions and the Chinese tourism authority. A questionnaire survey was also conducted in the hotel sector exploring further supporting evidence.

Given the unique government-oriented business structure of Chinese tourist industry, the research has been focused on interviewing the key representatives of these sectors. Quantitative data has only been collected within the hotel sector with a sample size of 30 hotels randomly chosen from the 1903 Star and above hotels located in Beijing. 


\section{Research Findings}

As this is one of the very first attempts to understand the transformation of the Chinese tourism industry through ICT and the Internet, it is exploratory by nature. It concentrates therefore on understanding the dynamic changes as well as the factors that motivate these changes rather than measuring and assessing the changes. As the research is exploratory in nature, key issues are highlighted for each industry sector and it also provides an initial understanding of the characteristics of the eTourism development in China. Evidently the tourism industry in China is heavily regulated with a high degree of government intervention. This is particularly the case for the air transportation.

\subsection{Air Transportation}

As the focus of the interview was to understand the current status of ICT integration with their businesses, and possible impacts of ICT adoption on the organisational structure, only those interviewees who understood both the enterprises' strategy and the ICT adoption status within the company were chosen in the study. The interviews in the air transportation sector were conducted with a number of key decision makers in Chinese eTourism. They included the marketing director of Travelsky (Beijing representative of Galileo); the director of computing centre of Beijing Capital International Airport; the yield manager of Air China; the PR manager of China Southern Airlines; the sales manager of United Airlines (Beijing office); and the ticketing manager of CITS (China International Travel Service) ticketing office.

\subsubsection{Computer Reservation System and Electronic Distribution}

\section{GDS in China: Travelsky}


IT application in the airline industry in China can be classified into four categories: airline management, ticket reservation, airport check-in and cargo handling. As an industry strictly controlled by the central government and its air authority, Civil Aviation Administration of China (CAAC), all the above systems were solely developed and provided by the only supplier in China, TravelSky Technology Limited. This company used to be known as Civil Aviation Computer Information (CACI). Systems provided by TravelSky include Inventory Control System (ICS) which became operational in 1985; Airport Passenger Processing system (APP) launched in 1988; Air Cargo System (ACS) started operation in 1994; and Computer Reservation System (CRS) launched in 1996. In 1999, the website based on the company's data network, www.travelsky.com, was launched.

According to the information provided by the marketing director of the company, Ms. Jia Lin, the TravelSky Computer Reservation System handles almost all business of the Chinese airline industry, as illustrated in Figure 1 . This includes $97 \%$ of domestic ticketing and $75 \%$ of overseas ticketing. It provides inventory management solutions for all 25 airlines in China, both local and national. The system also handles passenger transactions for all major domestic airports, and the total number of supported airports will reach 100 by the end of 2002 . According to the government regulation, Travelsky's reservation system is the only GDS within China allowed to issue tickets with its e-Terminals that connects all ticketing agents, of which 500,000 are domestic ticketing agents and 1 million are international. All major GDSs (four global ones Amadeus, Sabre, Galileo and Worldspan, and three regional ones in Asia - Infini, Axess and Topas) are linked with Travelsky.

\section{FIGURE 1 HERE}

With regarding Travelsky's future development strategy, there are two strategic directions: Firstly further enriching the airline CRS system into a complete GDS of all tourist products, mainly hotels. 
Secondly developing its website into a B2B (Business to Business) platform, a fully functional Internet booking engine (IBE). The current website can only offer real-time flight information. However, the prospect of e-ticketing or ticketless travel based on Internet is assessed as remote in China for the next five years. The difficulties, quoted, included the settlement problem, i.e. the ticket-based settlement plan between airlines and between airlines and travelers; the government (CAAC) policy that every ticketing agent has to have a office making online ticketing agents impossible; and airlines unwillingness to sell seats directly online. Due to lack of mutual trust for any online transaction.

Travelsky treats the opening up of the Chinese airline market to foreign airlines and foreign GDSs as the major challenge after China entered the World Trade Organization (WTO). Foreign GDSs rather than the Internet, will be the greatest threat to Travelsky. As indicated above, Travelsky believes that the real B2C (Business to Consumer) market based on the Internet is not yet mature and will not be the case for at least another five years. However, the opening up of the GDS market to foreign systems is totally up to a governmental decision, which may be implemented in the next a year or two. Although foreign GDS will need a certain period of time to get used to the Chinese market, but as soon as they are localised they will be much more competitive than Travelsky in terms of information richness, connectivity, processing speed and system stability. Hence the GDS market is expected to be transformed in the future. This will challenge Travelsky's domination but may provide access to technological advanced systems and greater access to international markets.

\subsubsection{Suppliers: Airlines}

Interviews with Beijing Capital International Airport, Air China and China Southern Airlines' executives demonstrated that respondents are satisfied with the current ICT applications monopolised by CACI. Travelsky have little intention to change. On the one hand, they are not 
able to establish their own system because of both policy prohibition and restriction of cost and time in building the whole system and data network by themselves. On the other hand, they cannot fully control their own operation, since the government handles most parts of their operation such as procurement, pricing, route design, and distribution. Hence they have no incentive to explore the benefits of ICTs or Internet applications because they may bring them more trouble.

The yield manager from Air China, the country's flag carrier airline and the largest international airline in China, gave a detailed description of the ICT applications in airline industry from another perspective. The ICT applications in Air China currently focus on distribution and inventory control. ICTs have little adoption within the enterprise except for an accounting system and an Intranet, which is mainly used for internal e-mails. In terms of the ticketing system, it currently uses Travelsky for all domestic ticketing, and foreign GDS for overseas distribution of international routes. The yield manager stated that the airline sincerely wishes to realise direct online selling to cut out commission costs. However, there are quite a few problems that make this wish unrealistic. First of all, the main problem as indicated already is the means in which the transactions are settled. In China, the majority (over 60\%, according to the yield manager) of air passengers are business travellers whose travelling costs are covered by their employers or working units. These travellers prefer settlement with company cheques as no personal cheque is available in China. On the leisure market, consumers prefer cash transactions, and they normally chase discount tickets offered by travel agencies. As the enterprise is directly controlled by the government airline authority (CAAC) Air China cannot respond to the market as a fully functional business. This is demonstrated in the following:

- The company cannot determine its prices according to market conditions.

- The company cannot control its own procurement and costs. Fuel suppliers, equipment suppliers, airports, CRS and other air computing system suppliers are all appointed by CAAC. 
- The company has no right to decide its own flight routes without permission of CAAC. The air routes within China as well as international routes are divided among various airlines by CAAC.

Due to the lack of autonomy, Air China does not have the incentive or power to develop its own ICT and Internet strategy. Therefore it has no intention to change the current distribution status with online direct selling, as they are not prepared to tackle all the above difficulties. However, with the rapidly expanding Internet, users in China and eCommerce are booming, some airlines did try to implement Internet solutions in their business operation, mainly in distribution. Air China has jointly developed an auto-ticketing machine system in co-operation with the Bank of China. The ticketing machine is a web-based CRS terminal, which is linked to the bank's ATM cash point. The concept is that consumers can use their cash card to buy a ticket at the cash point. After the transaction is completed, the bank's ATM machine will issue a receipt for customer. The customer can then exchange the receipt for tickets at the airport before check-in. The system is still under development and may be fully functional by 2004. China Southern Airlines and Hainan Airlines were the only two private airlines that considered to develop their own web-based ticketing and reservation system. However, the project failed due to the CAAC intervention.

Talking about the future, the yield manager of Air China expressed certainty that the Travelsky monopoly in China's airline ICT market will continue for at least another 10 years. First of all, the Chinese government will not open up this market for the next 5 to 10 years, according to her estimation. Secondly, even if foreign GDS are allowed to operate in China, it is not easy for Chinese airlines, airports, and air cargo companies to switch to another incompatible system. Thirdly, foreign GDSs are not competitive. Foreign GDSs charge US $\$ 3.5-3.8$ per transaction and are therefore much more expensive than Travelsky (US\$0.85 per transaction). Furthermore, due to the strict control over foreign GDS operation and their eagerness to make profit from the 
Chinese market, the commission over-riding problem is serious among those GDSs. Foreign GDSs encourage Chinese ticket agents to make two reservations and confirm both, one with Travelsky, who issues the tickets and another with a foreign GDS, which is later, cancelled. In that case, airlines have to pay two GDS transaction fees (one to Travelsky and one to the International GDS) for a single ticket. Foreign GDS, make money from false bookings, and refund a certain amount of commission to agents who make the reservation through them. A a result of the government intervention and the in-competitive pricing of international GDSs as well as the preference of Chinese travellers to bay by company cheques or cash there is little change anticipated in the Chinese distribution channels for airlines in China.

\subsection{Traditional Intermediary: Ticketing Agents}

In China all ticketing agents have to be authorised by CAAC with a certain amount of guarantee deposit. There are about 1.5 million air-ticketing agents categorised into two distinctive groups: A-type agents that can handle international flight ticket reservations, and B-type agents handling domestic ticketing. However, the boundary between the two has been blurred as many B-type agents issue international tickets from A-type agents and sell them to their customers. Some B-type agents develop their own agents, generally known as C-type agents.

The agent interviewed in this research is CITS Air Ticket Agent, an A-type agent. The agency is managed by the largest tour operator in China (China International Travel Service), and is the first IATA agent in China. In the year 2000, the agent adopted a web-based international flight ticketing system with its newly launched website www.citsair.com.cn. On this website, customers can view real-time flight information as well as prices (point to point only, not including transferring flights) updated everyday by a person in charge of data input. The cost is the discounted air ticket price plus the agency profit. So far, it is still the only website to provide the customer with both discounted prices and real-time flight information. When the customer 
makes a reservation on the website, after inputting certain information, the server automatically sends an e-mail to the agent's terminal. The agent then reads the e-mail and calls the customer to confirm the booking and wait for the money to be received before issuing the ticket. The system is manually maintained by the back-office staff, with flight information coming from Travelsky and Galileo. The price information is manually input into the database according to the contracts to different airlines and various documents issued by CAAC. After two years in operation, the online reservation system accounts already for one third of the agent's sales volume, with another one third of reservation by walk-in and call-in customers, and the rest by B-type agents coming to issue international tickets.

In comparing Travelsky with Galileo, the agent prefers Galileo as it provides more detailed information such as airport location, name of transferring city, transfer waiting time, flying time, correct prices etc. while Travelsky only displays how many en-route transferring stops and nothing else. Galileo is easier and more convenient to operate and is a much more stable system than Travelsky. However, due to the restriction of issuing BSP (bank settlement plan) ticket with only Travelsky's eTerminal, the agent has to use Travelsky for ticket issuing while browsing for information on Galileo.

When discussing the impact of the Internet, the sales manager of CITS ticket office, believes that there is no threat to the travel agencies in China in the near future and for at least 10 years. The reasons she gave included:

1) The complexities of international ticketing with various flight and price arrangements are too much for ordinary Chinese travellers. Even agents have to take weeks to get trained;

2) Customers tend to change their reservations frequently. That will cost airlines a lot of time and money to deal with these changes; and

3) Online settlements is a major barrier for any online transactions. Due to the preference for 
cash transactions among Chinese consumers. The under-developed banking system offers limited support for online purchasing, whilst credit card transactions are up to a 3\% service fee by the local banks, making online transactions unattractive. Neither customers nor suppliers would like to pay bank charges. From the agents' perspective, for each international ticket reservation, agents can receive 7-9\% commission from airlines. However due to severe competition, most agents hand part of their commission out to customers as discounts. Hence the profit margin left for agents is only $1-3 \%$, barely sufficient to cover bank transaction charge. Therefore although there are signs that there is a demand for Internet travel sales in China, growth is restricted by lack of trust between buyers and sellers, an underdeveloped banking system and advanced business models that do not encourage travel agencies to adopt Internet commerce.

\subsection{Hotels}

No central hotel reservation system exists in the hospitality industry in China. However, property management systems (PMSs) have been widely spread in hotels ranked as three-star or above. The majority of domestic invested hotels use Huayi and Zhongran (China Software), HIS (Hotel Information System) or PMS. Hotels built through foreign investments or operated by International hotel chains tend to use Fidelio, Landmark or other imported application software systems, in order to be compatible with other properties in their chain. ICT applications in hotels have concentrated on front-office functions, including reservation, reception, housekeeping, cashier, catering, marketing, customer relationship management, etc.

Hotel managers claimed that the major benefits of using front office systems and PMS are: increasing the efficiency and accuracy of internal information transmission; saving the costs of paper work and information-processing labour; and increasing the effectiveness of management, especially in terms of cash, account, stock and yield management. Few hotels use ICT in 
managing their back-office functions, including procurement, security, engineering, etc. Though most hotels were aware of the importance of back-office systems, few actually use such systems. Interviewees explained that the primary reason is concerns over costs. Training costs and possible position changes of certain personnel brought by the new system employment are additional factors that the hotel has to considered when deciding whether to apply an information system in back office departments. Several hotel departments such as engineering and procurement, often benefit from under-the-table commissions by blocking information access. Such benefits would disappear if all information is transparent and can be shared among all accessible people. This caused resistance from within the department. Hence they considered that it is much cheaper to purchase a front office system only, which is enough to keep the hotel running in good order.

Hotel distribution in China has been heavily relying on sales personnel mainly, as no CRS or GDS exist as an alternative channel. The Internet has been used by most hotels as a marketing information tool only. On-line reservations are not truly welcomed by hotels because of the lack of trust of consumers' credit. Without a deposit, many online reservations have been proved to be invalid bookings. Most hoteliers would rather trust telephone or fax booking. Hence, they request off-line confirmation for on-line bookings. When talking about Internet application in hotel operations, sales pointed out that many hotels do not have their own website, and do not trust online reservation at all. Several reasons were quoted: 1) since most people can book a hotel room by using telephone or fax paid by their company, why bother with the Internet; 2) online bank settlement is a major barrier to realised online reservations; 3 ) hotels cannot offer any discount for online reservations while customers can get a discounted rate by booking via a tour operator, booking centre, etc.; and 4) lack of mutual trust between customers and hotels, as 
invalid bookings happen quite often.

In order to explore further the Internet sales conditions in Chinese hospitality industry, a telephone survey was held among 30 hotels rated as 3 Star or above in Beijing. Sales managers of these hotels were questioned using a simple questionnaire. The data analysis results showed that: Firstly, Internet sales percentage is very low in hotels, accounted for $4 \%$ of total sales in average. Secondly, there is no correlation between Internet sale volumes and hotel indicators such as by the number of guestroom, occupancy rate and whether the hotel has its own website. Thirdly, the Internet sales among different hotels range from 0 to $40 \%$ although most hotels in Beijing do not have any Internet sales or reservations. Only one out of the 30 hotels reported $40 \%$ Internet sales, which come mainly from hotel reservation centre development by travel websites such as Ctrip (www.ctrip.com) and elong (www.elong.com). Finally, 3-star hotels generate higher sales percentage from the Internet. Among the 30 hotels, $86 \%$ of the 3-star hotels (6 out of 7) reported certain percentage of Internet sales (5-10\%) while only $55 \%$ of the 5 -star hotels ( 6 out of 11 ) and $58 \%$ of the 4 -star hotels (7 out of 12 ) reported Internet sales. Although hotels in Beijing start receiving bookings through the Internet, it is still early days for them. Lack of trust between sellers and buyers. Only rack rates being available and lack of developed business models are quoted as factors for the slow uptake of online booking on the Internet.

\subsection{Tour Operators}

Similar to most part of the world, the ICT adoption level in tour operators in China lagged behind the airlines and hotels. However, the situation is gradually changing, but at a very slow pace. Two adoption models exist, known as CITS (China International Travel Service) model and CYTS (China Youth Travel Service) model, both named after the tour operators who first adopted the model. 
The CITS model can be summarised as an ICT development platform from internal to external as illustrated in Figure 2. According to the company's information director, CITS started using its tour handling itinerary transmitting network in 1985. Recently they upgraded the system to connect to the head office with its local branches and contracted hotels in twenty cities within the country via the Internet. Other web-based business operations include hotel reservations, international train ticketing, international flight information, as well as outbound tour package information. The first two functions operated on the B2B (business to business) model, while the later two as B2C (business to consumer) model. Other business functions, such as cruise booking, passport and visa application processing, accounting, etc, have been accomplished by a separate client-server based intranet. In other words, all major business activities within the enterprise have been handled under the assistance of its ICT networks. Though no direct selling or B2C function has been in full play, the company believes that on the basis of high ICT adoption rate within the business, the B2C function on the Internet would be easily accomplished as soon as the external environment and market are ready.

\section{FIGURE 2 ABOUT HERE}

In contrast the CITS model follows the development route from external to internal, with the higher priority on the Internet website development concentrating on travel information and booking platform construction. However, according to CYTS information director, its website www.cytsonline.com.cn has little to do with the company core business, which is inbound travel handling due to the resistance of most department managers who are afraid that the total transparency of the information flow will affect their personal income, which comes from 
personal agreed commissions or some other underhand manners. Even with the website itself, the information director of CYTS is not optimistic. Since it first began operation in 1998, the website has operated at a loss so far. Though the website offers online information, reservations and bank settlements, the market acceptance rate is very low. The major constraint for consumers booking holidays online is that people would prefer face-to-face contact when making a decision of purchasing a holiday, a comparatively expensive intangible product.

Other than the three major tour operators, CITS, CYTS and CTS (China Travel Service), a large number of small and medium tour operators in China have little adoption of ICT facilities, other than using computer as a typing machine. Hence ICTs will not have a major impact on tour operations.

\subsection{Visitor Attractions}

This is the sector that uses information technologies least in its operation. According to a telephone survey among 20 attractions in Beijing, the capital city and the most famous tourist destination city in China, only two attractions (Blue Zoo Beijing and World Park, according to Beijing Tourist Authority) use an e-ticketing system, to handle their ticket sales, turnstile entry control, accounting, and on-site point-of-sales. All the rest of the attractions do not use any information network in their operation, except for a few, which use intranet's e-mail function to send messages. Though the two attractions using the e-ticketing system found it extremely helpful in cash management and acquiring market statistics, few other attractions show any intention to explore the possibility of using any information systems in their site management and operation. The reasons quoted included lack of money for ICT investment; not trusting technology; not seeing the benefit; being satisfied with current situation; and not willing to accept any changes at all. 
However it was surprising to find that all places of interest in Beijing have their own web pages providing information on the place but without any other function. According to the information director of Blue Zoo Beijing, it is an executive order given by Beijing tourist authority that requires all attractions to have their websites or homepages on the Internet by the end of year 2001. However, most interviewed attraction personnel do not update their websites at all. Some attraction websites are even thought to be inaccessible by now.

According to information director of Blue Zoo Beijing, a New-Zealand managed tunnel-style aquarium in Beijing, the Internet application of the attraction is limited. The company tried to provide online ticketing sales without success. In the year 2001, only two tickets were sold online. With such a small volume of sales, the company was reluctant to invest further in the system development. Hence, the online reservation function has been cancelled since 2002. For future development, Blue Zoo Beijing will still focus on applying technologies within the site rather than exploring the Internet usage. The recent step to be taken is to install few touch screen computers on site to facilitate an interactive aquatic life information distribution among visitors, in order to stir up people's interest in aquatic life and around their awareness of ocean resource protection. Despite Beijing tourism authority requiring attractions to build and operate websites, attractions are still reluctant to explore eCommerce and apply eCommerce.

\subsection{Tourism Authority: China National Tourist Administration}

The tourist authority in China is called China National Tourist Administration (CNTA), was established in early 1980s. It plays a role of both tourist industry authority auditing the operation of tour operators, hotels and tour education institutions in China and destination image promoter via its overseas branches.

As airlines, railway and cruise were controlled by CAAC, Railway Ministry and Transportation 
Ministry respectively, CNTA also collaborates with these bodies. Local tourism boards have been established at both provincial level and municipal level, under the leadership of both CNTA and local government. As the only destination management organization (DMO) in China, CNTA has adopted computer network systems since 1992, primarily focusing on accounting, statistics and issuing tourist information CD-ROMs.

In CNTA, $90 \%$ of office staff have been using computers connected with the administration intranet, composed of four SQL servers, and linked with Internet via a $2 \mathrm{~m}$ DDN. As demonstrated in Figure 3 the main function of the system is to deal with office paperwork. Since 1993, the server has been linked with local tourism boards at provincial level and municipal level to collect statistical data on a monthly base. In 1997, the official destination tourist website, www.cnta.gov.cn, was developed for the purpose of marketing and promotion, providing destination information on accommodation, accessibility, attraction, catering, shopping and entertainment.

\section{FIGURE 3 HERE}

Along with the quick development of domestic tourism, especially during the three golden weeks on public holidays of May Day, National Day and Spring Festival, the National Holiday Tourist Forecasting System started its operation on September 21, 2000. With such a system, tourist arrivals on all major tourist cities and visitor attractions and accommodation supply will be forecasted daily and publicised on the CNTA website as well as on other mass media, during the three golden weeks. People intended to travel can adjust their destination choice according to the forecasting results in order to avoid being caught in overcrowded attractions or cities.

In March 2001, CNTA conducted a survey of ICT adoption rate among 49 provincial and 
municipal tourism boards in China. According to the survey, the average IT adoption level is very low, both in terms of computer facilitation, trained personnel and communication infrastructure used. Only one third of all tourism boards are fully equipped with internal information management system that can be readily connected with the national information networking system, known as Golden Travel Project, the latest move on ICT of CNTA.

The Golden Travel Project was planned by CNTA in the year 2000, and developed and controlled by its Information Center. The target of the project is to create a tourist management and e-commerce network system covering the whole country by 2005 . The project is composed of two parts: industry management network, a web-based system connecting the CNTA with local tourism boards at different level, other governmental departments, and tourism enterprises, or even tourists; and a tourist e-commerce website www.yahtour.com.cn aiming to creating a web-based e-marketplace for tourist product transactions via B2B and B2C models.

According to the Director of CNTA Information Center, whose opinion represents the views of government in e-tourism application in China, e-tourism application in China can be divided into two parts: ICT adoption and Internet involvement. In terms of ICT adoption, he pointed out that China had lagged behind Europe and America for about 10 to 15 years. He attributed such situation to five major issues:

- Lack of synergy among various sectors within the industry, i.e. without a networking system involving all players of the industry, the advantage of IT can hardly be fully recognized;

- Lack of infrastructure required such as communication bandwidth, technicians, inf0ormation and processing standards, etc.;

- Lack of information service providers and intermediaries to assist tourist enterprises;

- Fear of business/management process reengineering caused by technological innovation such as unwillingness to learn new knowledge, losing control of information or power, 
altering the habit of a life time formed by traditional business environment, adjusting new environment;

- The information security problem, which is in a sense of cultural concern rather than technological.

The e-government management can only be built on the basis that all or most enterprises within the industry have been fully converted into e-businesses. However, this is far from the truth of Chinese tourism industry. In the current situation, the government should shoulder the responsibility and take the lead in the industry e-transformation. On one hand, the government can invest in information infrastructure development. On the other hand, the government can push enterprises' e-business transformation by either executive orders or other compulsory means, especially when currently many companies do not realise the importance and necessity of such transformation. For example, as CNTA requested that all yearly inspection documents of tourist companies have to be reported online, many companies have to build up a compatible system to connect with CNTA's network for such purpose.

The Internet involvement of the Chinese tourism industry has proved to be a failure and there are several reasons for this. Comparing with the counter-parties in America and Europe, many Chinese tourism companies had little idea of what e-business really is when they rushed to jump on the bandwagon, failure to reap real benefit from the Internet involvement as tourist companies in America and Europe did. The fact that many tourist companies invested a lot money in website development and end up with no business returns discouraged them to give further input to explore the opportunities brought by the Internet. The e-business development upsurge came too early to the Chinese tourist industry, and neither consumers nor suppliers were ready for it. Perhaps the government should play a role of promoter and organizer in this 
area by providing certain guidance and assistance for enterprises.

\section{Discussion and Conclusion}

The Chinese tourism industry has followed a similar pattern in the development of ICT applications as Europe and America. The development was first started in airlines, and then extended to hotels, tour operators, attractions and DMOs, with the first two sectors taking the lead. It is true that airlines and hotels are comparatively mature and in the last few years they developed in terms of their ICT adoption within the organisation and the awareness of ICT. Though some changes have taken places in tour operators, visitor attractions and DMOs, ICT applications in these sectors are limited. The research findings in this study explore a general picture of Chinese eTourism development status.

Other than the developing unbalance among different sectors of tourism industry that is similar to developed countries, a few factors make IT adoption and Internet application development in China a very unique and special case, and a highly complicated one to understand. The following factors and issues can be clarified as important in shaping the country's e-tourism development framework.

First, China's tourism development is very much inbound oriented. Companies involved in handling international tourists, including inbound tour operators, 4 and 5 star hotels that cater for foreign tourists, and airlines, are well established, and comparatively matured. Inbound tourism is also heavily controlled by established intermediaries. However, the demand for eTourism or the driving force of ICT and Internet adoption in tourism lies in domestic and outbound tourist market. The mismatch between supply-demand market can partly explain the stagnation of eTourism developments in China. 
Secondly, the structure of Chinese tourism industry is different from that of the developed countries, as it is mainly inbound oriented. The whole industry in China is simply the supply section of the whole tourism system as demonstrated in Figure 4. The consumers and intermediaries are all from source countries that are out of the scope of this research. The examining China's tourism industry structure, demonstrates that another problem emerges and consumers and intermediaries from the West expect to interact fully with Chinese tourism companies and government. Only suppliers - airlines, hotels, inbound tour operators and attractions have adopted ICT and Internet, while intermediaries are lagged far behind. Only when looking at domestic and outbound tour market, a few newly set-up ticketing agents and hotel booking centres can be found.

\section{FIGURE 4 HERE}

Thirdly, the market is not fully operational as it functions under strong government intervention and policy guidance. Most tourist companies in the market are not qualified enterprises that can respond to market signals in pursuit of profit maximisation. Some or most parts of the business functions are controlled directly or indirectly by government agents, rather than by companies themselves. Individual companies therefore have no power and motive to search for ways to gain a competitive edge by reducing costs and increasing operational efficiency.

In the evolution history of IS (Information System) / IT (Information Technology), four stages are generally referred to in describing its growing importance in business world: data processing; IS management; strategic IS; and networked IS. In China's tourism industry, the research results showed that most tourist companies still simply use ICT as a data processing tool to handle simple document processing as the situation in most tour operators, visitor attractions as well as local tourism boards (DMOs). Some have developed the internal usage of ICT as a management 
tool in controlling most of primary business activities defined in the value chain model (Porter \& Millar, 1985), such as in most star-rated hotels and airlines. However, none of interviewed or questioned companies had ever strategically integrated ICT application with all activities in the value chain. Even less has been done in networked ICT facilitation among value chains with the industry value system. Judging from the rough time division based on the four-stage IS/IT evolution model, as illustrated in Figure 5. The e-business development in Chinese tourism today is equivalent to developed countries in 1970s, 30 years ago, if not earlier.

\section{FIGURE 5 HERE}

\section{Impact of the Internet and Relating Issues}

Despite some ICT development, the Internet did not bring Chinese enterprises as much benefit as they expected. The majority of tourist enterprises in China still do business in traditional way with little application of an information network. Furthermore, even the e-businesses and Internet-based network companies are looking for ways to combine online e-commerce with offline operations. Few issues can be concluded from this research to be the most important barriers to eTourism in China.

- The settlement problem: lack of trust toward both consumer and supplier, and network security issues are still major worries and barriers for tourist companies to explore online opportunities.

- The business operation tradition and consumption culture keep people away from embracing the new technology and Internet. It may change along with time, but this will be very slow. From the aspect of tourist companies, the low development level of ICT adoption in their business activities of corporate value chain and external industry value system make it harder for them to jump from traditional business to an e-business, by-passing all the development stages in between. 
- The Internet is also creating intermediaries in Chinese tourism rather than cutting out the middlemen. With the Internet and e-business booming in the last few years, travel network companies explored the market opportunities and quickly filled in the gap. Up to now, the two most successful travel websites, Ctrip and elong, the only two travel webs in China that claim to have made a profit in 2001, have benefited from positioning themselves into accommodation booking e-mediaries. Ctrip however claimed that over 80 percent of its profit came from the hotel reservation center, an offline-booking center handling online reservation. The company declared its plan in 2002 is to open a hotel reservation call center to increase its booking volume.

\section{Future Trends}

The future development of e-tourism in China will depend on how well the above problems and issues be tackled, and how long the process will take. It will definitely take China a very long time to have its eTourism and Internet adoption level developed to the current stage in Europe or America. How long will it be decided by several involved stakeholders: companies, consumers, government and even the social culture. The transformation of way of doing business and consumption habits and attitudes will take a rather long period of time. Furthermore, given the unique government intervention economic development pattern, the role of tourism and other related government authorities play will also determine the direction and speed of China's e-tourism development. Still, taking the huge potential market of China, it is reasonable to be optimistic for its e-tourism developing future. Though the e-boom from 1998 to 2000 did not bring revolutionary changes to the structure of China's tourist business and industry, it did shake the industry and attracted more attention to the impact of IT and Internet. The situation has changed already and at a growing speed. The growing IT awareness and market demand will lead China's tourism into an IT intensive era, and ultimately the e-Business era. 



\section{References}

Alford, P. (2000). e-Business in the Travel Industry. UK: Travel \& Tourism Intelligence.

Buhalis, D. (1993). RICIRMS as a strategic tool for small and medium tourism enterprises. Tourism Management, 14 (5), 366-378.

Buhalis, D. (1998) Strategic use of information technologies in the tourism industry. Tourism Management, 19(3), 409-423.

Buhalis, D. (2000). Marketing the competitive destination of the future. Tourism Management, 21(1), 97-116.

Buhalis, D. (2003). eTourism: Information Technology for Strategic Tourism Management, London: Pearson.

CNTA. (2001). The Yearbook of China Tourism Statistics. Beijing: China Tourism Press.

Cooper, C., et al. (2000). Tourism: Principles and Practice. London: Longman.

He, G., Sun, G., \& Zhong, H. ( 2001). Tourism Information Program (in Chinese). Beijing: CNTA Information Center.

Inkpen, G. (1998). Information Technology for Travel and Tourism ( $2^{\text {nd }}$ ed.), London: Longman.

Lang, T. C. (2000). The effect of the Internet on travel consumer purchasing behaviour and implications for travel agencies. Journal of Vacation Marketing, 6(4), 368-385.

Lew, A. \& Yu, L. (1995) Tourism in China: Geographic, Political, and Economic Perspectives, Oxford: Westview Press.

Martinsoms, M. (2002) Electronic commerce in China: emerging success stories, Information \& Management, 39, 571-579.

McGregor, R. (2002). World Cup helps lift Chinese Internet portals, Financial Times, July 18, 2002, p17.

O'Connor, P. (1999). Tourism \& Hospitality Distribution and Information Technology, Oxford: CABI.

O'Connor, P. (2000). Using Computers in Hospitality ( $2^{\text {nd }}$ ed.), London: Cassell.

Palmer, A. \& McCole, P. (1999). The virtual re-intermediation of travel services: a conceptual framework and empirical investigation. Journal of Vacation Marketing, 6 (1), 33-47.

Poon, A. (1993). Tourism, Technology and Competitive Strategies. Oxford: CABI.

Porter, M. and Millar, V. (1985). How information gives you competitive advantage. Harvard Business Review, July-August.

Sheldon, P. (1997). Information Technologies for Tourism. Oxford: CABI.

Standing, C. and Vasudavan, T. (2000). The impact of Internet on travel industry in Australia. Tourism Recreation Research, 25( 3), 45-54.

Werthner, H., and Klein, S. (1999). Information Technology and Tourism - A Challenging Relationship. Austria: Springer-Verlag.

WTO (2001). e-Business for Tourism: Practical Guidelines for Tourism Destinations and Business, Madrid: WTO. 

FIGURE 1 TRAVELSKY COMPUTER RESERVATION SYSTEM IN THE CHINESE AIRLINE

\section{INDUSTRY}

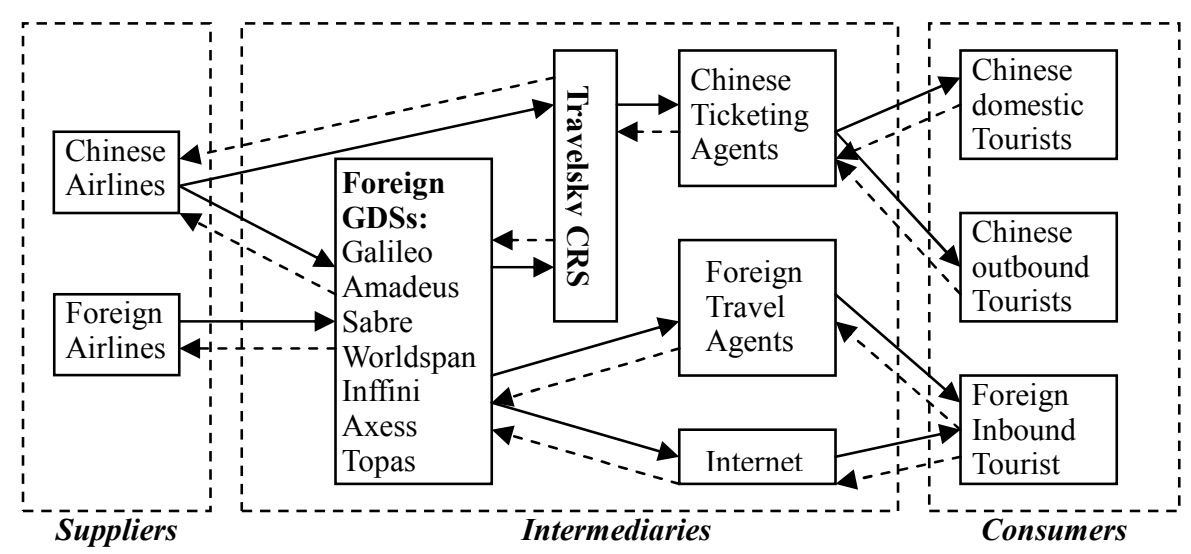

Notes: $\longrightarrow$ distribution channels $--\rightarrow \quad$ reservation channels 
FIGURE 2: INTERNAL SYSTEM FRAMEWORK OF CITS HEAD OFFICE

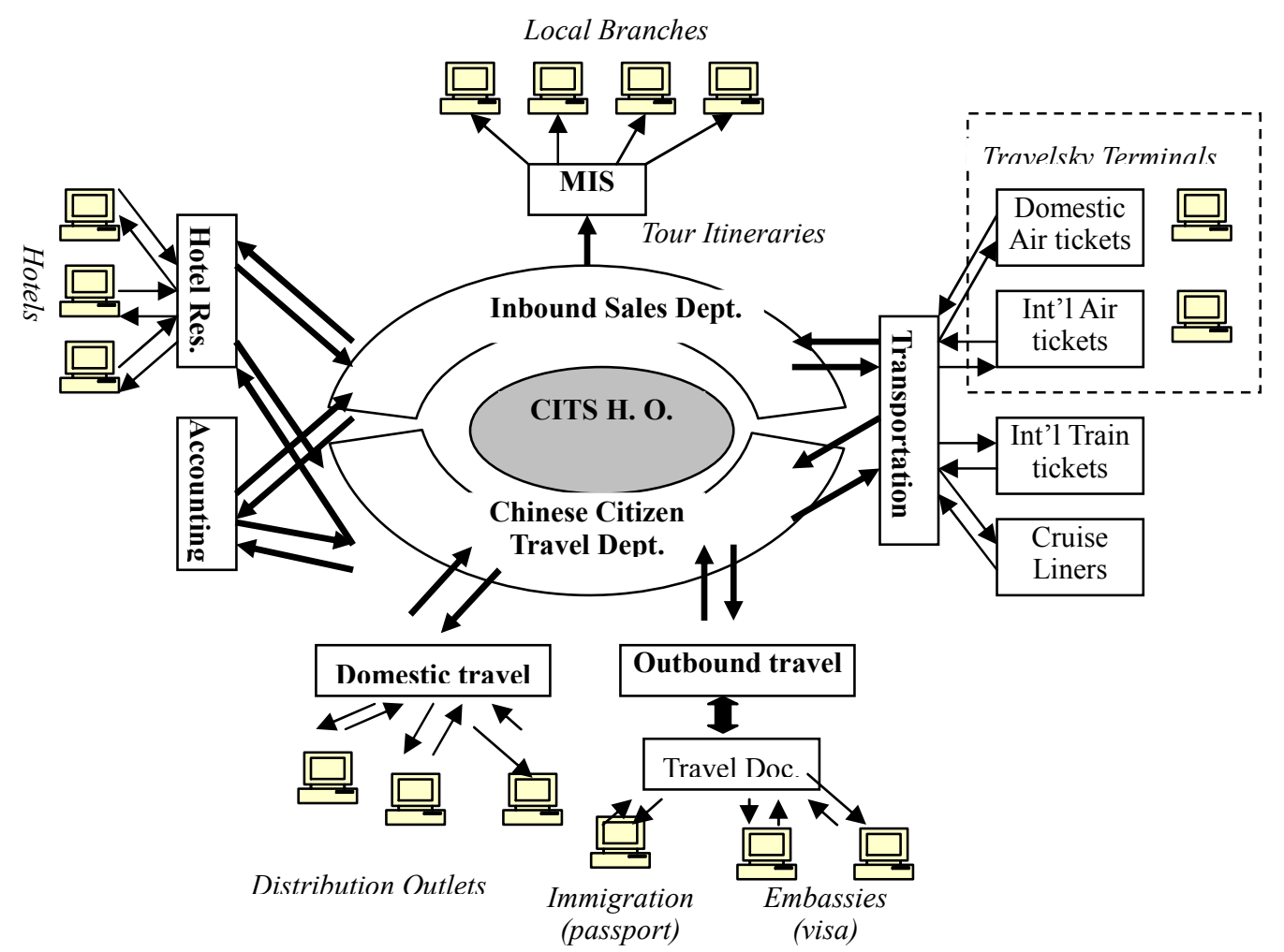


FIGURE 3 CHINA NATIONAL TOURISM ADMINISTRATION SYSTEM

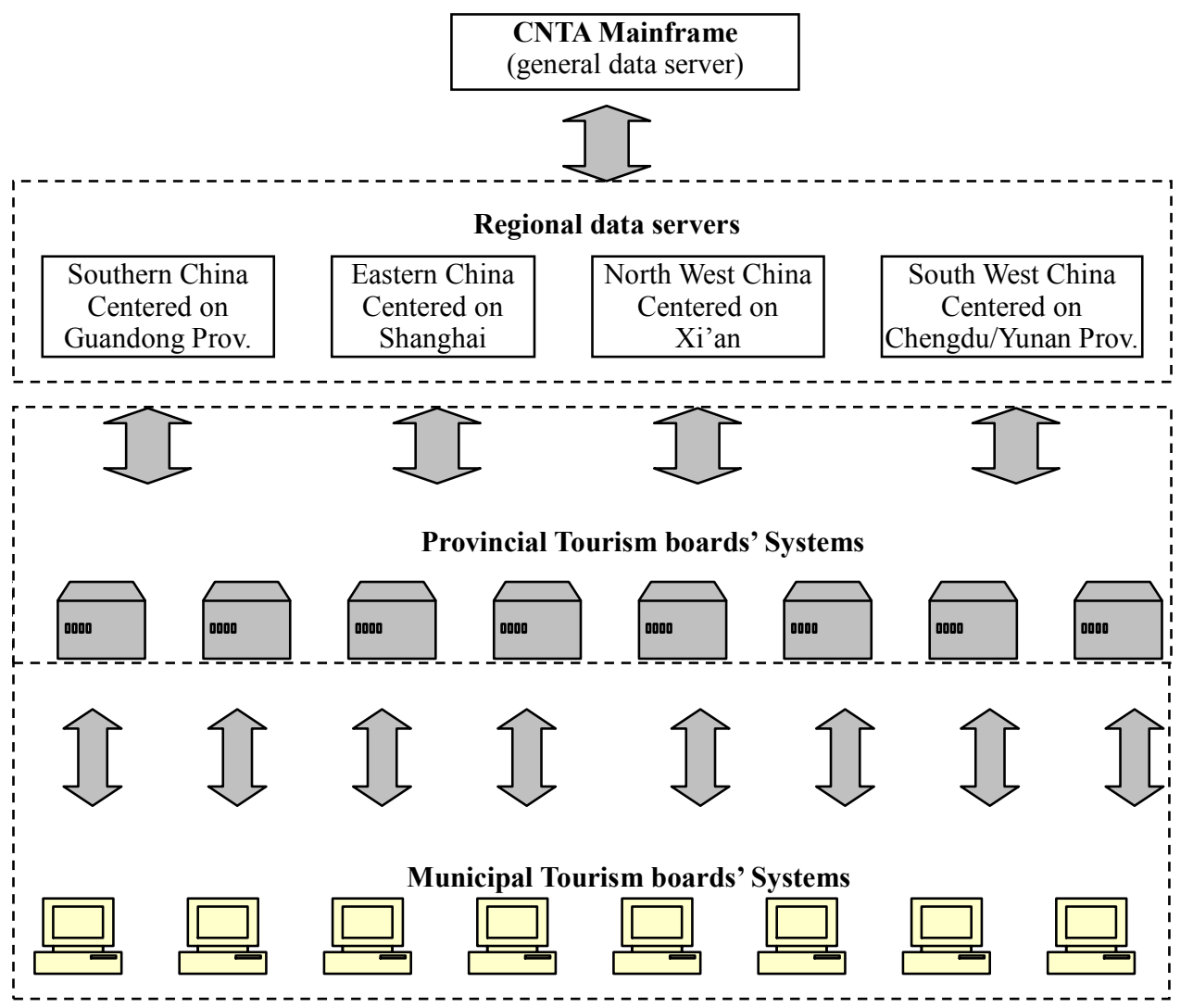




\section{FIGURE 4 TECHNOLOGY SUPPORTED TOURISM SYSTEM IN CHINA}

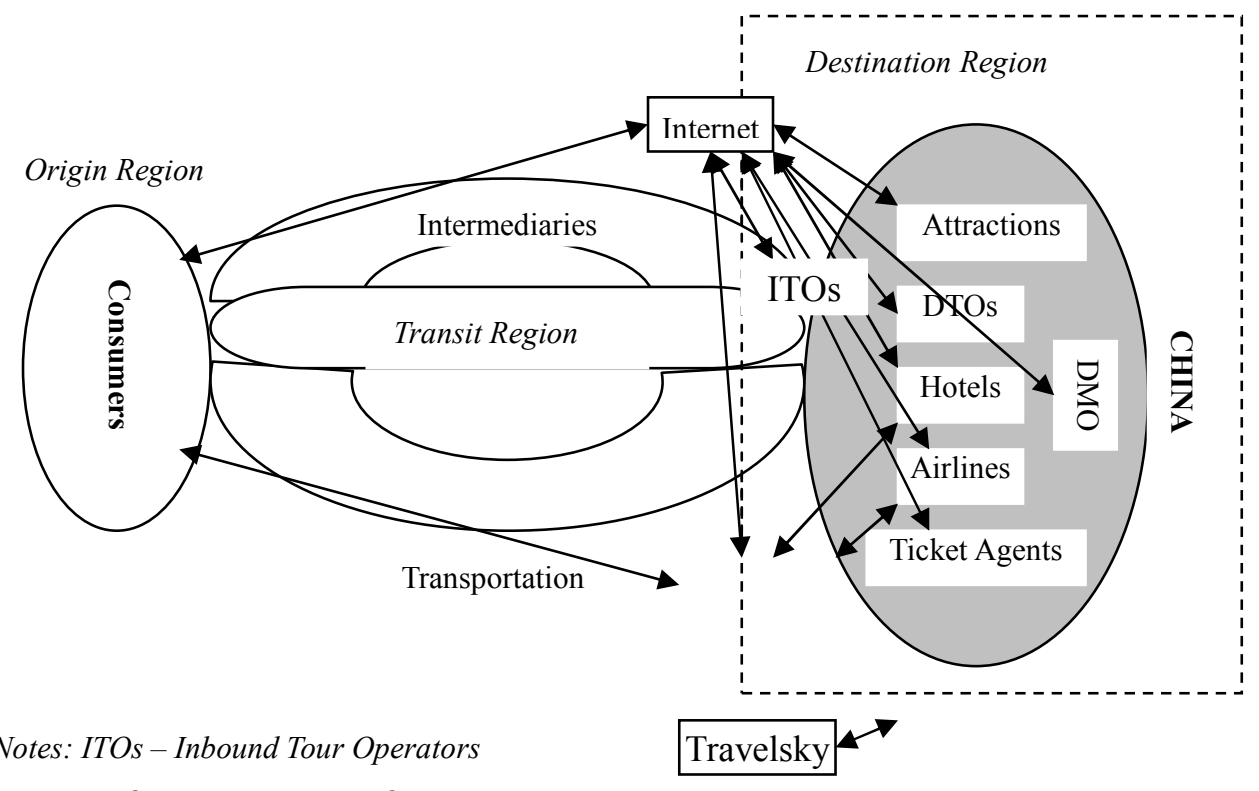

DTOs - Domestic Tour Operators

DMO - Destination Management Organization

After Buhalis, 200 


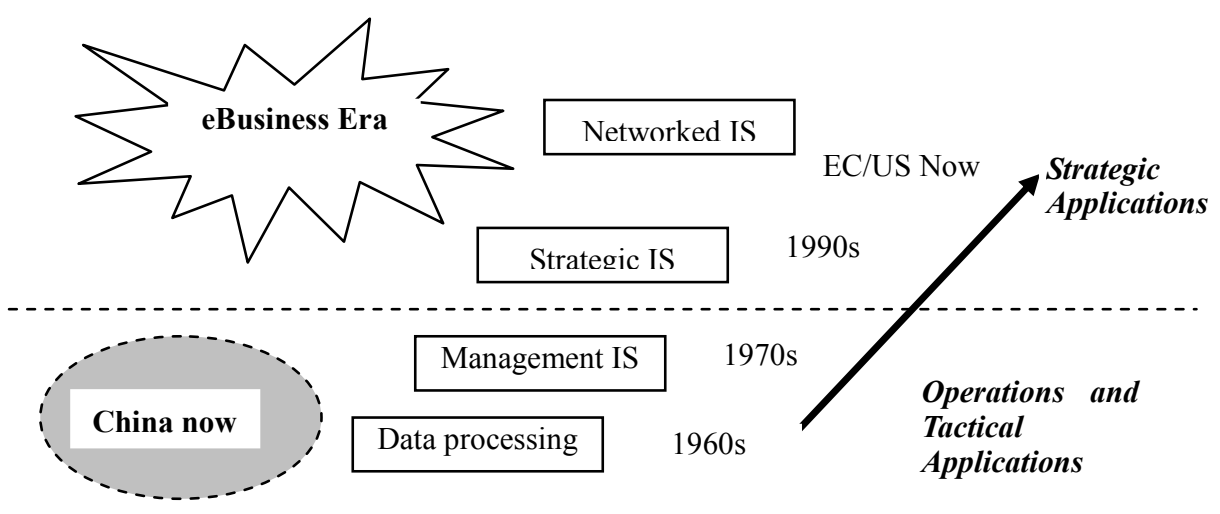

